\title{
Acute urinary retention after Black Widow envenomation: a case report
}

\author{
Matthew Carere, BSc, MD*; Russel Sterret, BSc, $\mathrm{MD}^{\dagger}$; Nicholas Timmerman ${ }^{\ddagger}$; Ian Taylor, BSc, $\mathrm{MD}^{\S}$
}

\section{ABSTRACT}

Latrodectism following Black Widow envenomation is rare in Canada. We present the case of a previously healthy 50 year old male who presented with an acute abdomen, hypertension, and urinary retention. After a thorough work up it was determined to be as a result of a Black Widow spider bite. Due to climate change we may see more cases of Latrodectism in the future and it should be considered as a differential diagnosis in anyone presenting with an acute abdomen after an insect bite.

\section{RÉSUMÉ}

Le latrodectisme à la suite d'une envenimation par une veuve noire est un phénomène rare au Canada. Sera exposé ici le cas d'un homme de 50 ans, auparavant en bonne santé, ayant des douleurs abdominales, de l'hypertension et de la rétention urinaire. Après un bilan complet, nous en sommes arrivés à la conclusion que le latrodectisme découlait de la piqûre de veuve noire. Il se peut qu'en raison des changements climatiques on observe davantage de cas de latrodectisme à l'avenir, et le syndrome devrait être envisagé dans le diagnostic différentiel chez toute personne souffrant de douleurs abdominales après une piqûre d'insecte.

Keywords: latrodectism, envenomation, insect

\section{CASE REPORT}

Latrodectism is the clinical term used to describe the local and systemic clinical manifestations that result from Black Widow spider bites. Clark et al. ${ }^{1}$ conducted a review of 163 cases of widow bite envenomation and described a three-grade scale to characterize the severity of the syndrome. The mildest form of latrodectism is characterized by pain near the site of the bite. Moderate latrodectism involves muscle pain of the entire extremity; diaphoresis and piloerection at the site of the bite and possibly the entire extremity; and abdominal pain that can mimic an acute abdomen. Severe latrodectism is characterized by diaphoresis remote from the site of the bite; generalized muscular pains, nausea, vomiting, hypertension, and tachycardia. ${ }^{1}$ Other symptoms including myocarditis and priapism can also be seen, though these are rare. ${ }^{2,3}$

We present the case of a previously healthy 50 -yearold male who presented to a community emergency department (ED) in southern Ontario with a primary complaint of abdominal pain and urinary retention after an insect bite. The abdominal pain started suddenly early that morning and was diffuse and crampy in nature. It was associated with urinary urgency, frequency, and diaphoresis. Initial investigations revealed trace hematuria and a mildly elevated lactate level $(3.5 \mathrm{mmol} / \mathrm{L})$. Based on the presumptive diagnosis of renal colic and after dismissing the insect bite as coincidental, the patient was discharged home with analgesia, and follow-up imaging was arranged for an outpatient visit.

The patient re-presented to the same community ED later that afternoon with recalcitrant abdominal pain. Repeat blood work showed persistent lactic acidemia $(3.8 \mathrm{mmol} / \mathrm{L})$. He was referred to the nearest tertiary care ED for definitive imaging.

Upon presentation to the tertiary care centre, the patient was visibly uncomfortable and profusely diaphoretic with bilateral eyelid edema. The edema was limited to the periorbital region. The abdomen was diffusely rigid with guarding. There was no rebound or flank tenderness. His cardiorespiratory examination was completely unremarkable. His vital signs revealed a mildly increased temperature $\left(37.5^{\circ} \mathrm{C} / 99.5^{\circ} \mathrm{F}\right)$; he was profoundly hypertensive $(210 / 128)$ with the other vital signs within normal limits. Repeat bloodwork including urinalysis, liver function tests, lipase, and a venous blood gas revealed no abnormalities.

From the *Department of Emergency Medicine, University of Ottawa, Ottawa, ON; †Department of Internal Medicine, University of Ottawa, Ottawa, ON; ¥Faculty of Medicine, University of Ottawa, Ottawa, ON; and §Arnprior Hospital, Arnpior, ON.

Correspondence to: Dr. Matthew Carere, 1053 Carling Ave, Ottawa, ON, K1Y 4E9; Email: Matt.Carere@gmail.com 


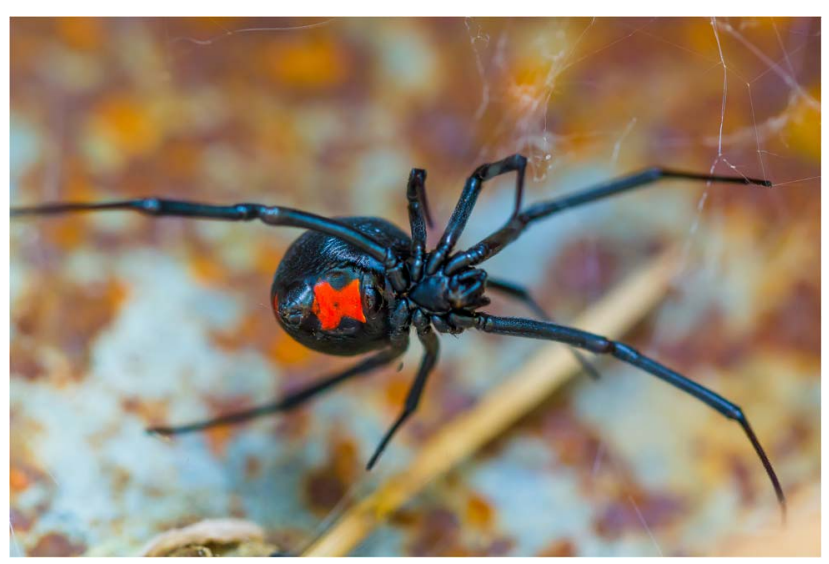

Figure 1. Western Black Widow spider or Latrodectus hesperus is characterized by a red hourglass shaped marking on the underside of the body. Photo by Sharon Keating / Adobe Stock, reproduced with permission.

Further questioning revealed that during the preceding evening while walking through tall grass at a cottage, the patient sustained what he believed to be a spider bite. The bite initially was little more than an annoyance, but after two hours, it had progressed to excruciating pain. He could sleep that night but awoke early in the morning with severe abdominal pain prompting his first emergency department visit.

A more thorough examination of the patient's skin in the ED revealed no evidence of an arachnid bite or a rash. During his stay in the ED, he did develop severe episodic bilateral lower extremity pain, which was worse along the soles of his feet bilaterally. A computed tomography (CT) scan of the abdomen revealed a massively distended bladder (above the level of the umbilicus) with no other abnormality. A Foley catheter was placed that drained approximately one litre of clear urine. After consultation with a toxicologist, the patient was treated for a suspected Black Widow spider bite with supportive care.

The patient was admitted to the General Medicine service. He was administered intravenous fluids, opioids for pain control, and amlodipine for his elevated blood pressure. His pain had improved substantially by the second day of his admission. His Foley catheter was removed, and the patient could void spontaneously. After careful consideration of other possible explanations for the patient's constellation of symptoms such as benign prostatic hypertrophy, thyroid storm, neuroleptic malignant syndrome, and other toxicological syndromes, he was discharged home in stable condition two days after his presentation with an empirical diagnosis of widow spider bite envenomation.

\section{DISCUSSION}

Black Widow spiders are rare in Canada and predominantly found in southern regions along the Canada-United States border. ${ }^{4}$ They require a warmer climate, which explains their border distribution and highest concentration in southern Ontario. There are two species of Black Widows in Canada. British Columbia and Manitoba are populated by the western Black Widow (Latrodectus hesperus; Figure 1), whereas southern and eastern Ontario are populated by the northern Black Widow (Latrodectus variolus). ${ }^{4}$

The venom from a Black Widow spider contains a variety of toxins including alpha-latrotoxin. This toxin leads to massive exocytosis of cells from presynaptic membranes leading to release of various neurotransmitters (glutamate, gamma-aminobutyric acid [GABA], acetylcholine, and catecholamines). The release of these neurotransmitters helps to explain the varied symptoms of latrodectism (including, but not limited to, tachycardia, hypertension, muscle rigidity, muscle pain, and diaphoresis). Most cases of latrodectism completely resolve without intervention by 72 hours. Careful attention to the history is important as skin manifestations from envenomation are nondescript (usually urticaria and erythema with or without a central punctum) and may be absent altogether. ${ }^{1,5}$ While many cases of latrodectism can be managed symptomatically with intravenous opiates and benzodiazepines, a minority of cases require antivenin for severe symptoms (hemodynamic instability and severe pain). However, antivenin should only be used in consultation with a toxicologist as severe side effects such as anaphylaxis can occur. ${ }^{6}$

Black Widow spider bites are exceedingly uncommon in Canada. ${ }^{7}$ However, because of climate change and the necessity for a warmer climate for spider reproduction, we may encounter more cases of latrodectism in the future. ${ }^{8} \mathrm{We}$ presented the case of a previously healthy male who presented with an acute abdomen and urinary retention. Although other diagnoses were considered, after appropriate imaging and investigation, the presumptive diagnosis of severe latrodectism from a northern Black Widow spider was made, and the patient was treated symptomatically.

Competing interest: None declared. 


\section{REFERENCES}

1. Clark RF, Wethern-Kestner S, Vance MV, Gerkin R. Clinical presentation and treatment of black widow spider envenomation: a review of 163 cases. Ann Emerg Med 1992; 21(7):782-7.

2. Isbister GK, Fan HW. Spider bite. Lancet 2011;378 (9808):2039-47.

3. Offerman SR, Daubert GP, Clark RF. The treatment of black widow spider envenomation with antivenin latrodectus mactans: a case series. Perm 7 2011;15(3):76-81.

4. Nature Conservancy Canada. Black Widow. Available at: http://www.natureconservancy.ca/en/what-we-do/resourcecentre/featured-species/black-widow.html (accessed September 19, 2016).
5 Muller GJ. Black and brown widow spider bites in South Africa. A series of 45 cases. S Afr Med $\mathcal{F}$ 1993;83(6): 399-405.

6. Südhof TC. Alpha-Latrotoxin and its receptors: neurexins and CIRL/latrophilins. Annu Rev Neurosci 2001;24(1): 933-62.

7. Government of Canada. Health. Spiders; 2013. Available at: http://healthycanadians.gc.ca/product-safety-securite-produits/ pest-control-products-produits-antiparasitaires/pesticides/ tips-conseils/spiders-araignees-eng.php (accessed October 31, 2016).

8. Livescience.com. Brown Recluse Spiders May Invade Northern US as Planet Worms. Available at: http://www. livescience.com/13909-brown-recluse-spider-range-climatechange.html (accessed October 31, 2016). 